\title{
On the Problem of Realizing the Rights of Landholders in the Civil Law of the Continental Europe Countries (On the Example of France and Germany)
}

\author{
Natalya N. Simachkova \\ Ural State University of Economics \\ Yekaterinburg, Russia
}

\author{
Oksana S. Trotsenko \\ Ural State University of Economics \\ Yekaterinburg, Russia \\ trocenko.o@mail.ru
}

\author{
Svetlana N. Burlaka \\ Ural State University of Economics \\ Yekaterinburg, Russia
}

\begin{abstract}
Private land ownership in modern Russian law is, on the one hand, a legal novel, taking into account the almost century-old failure of the development of private land relations, and, on the other hand, the Russian legal doctrine is closely connected with continental legal institutions, including property law. European legal structures influence the Russian legal system, its formation and evolution from the moment of reception of Roman law and the creation of the Code of Napoleon.

In Russia, the land reform, which began in the late 90s, is ongoing, an important aspect of which is the realization of the rights of landholders to their land plots. Until now, some issues related to the right of the owner to dispose of his/her land plot are debatable. In this context, it is important to study the European legal experience of the realization of the rights of landholders in the continental Europe countries by the example of the leading legal systems of France and Germany.

In the scientific literature, there are practically no special works devoted to a comprehensive study of the problem of the realization of the rights of landholders in the civil law of the continental Europe countries. A number of researchers: E. Anners, R. David, C. Jauffret-Spinosi, I.M. Kulisher, and others, consider the problems of the formation and evolution of European legal institutions, but do not dwell separately on the problems of the realization by the landholder of their rights. Therefore, using modern scientific tools, scientific research methods: retrospective, systemic, analytical methods, rather-legal analysis, etc., it seems to us possible to consider the problem of realizing the rights of landholders in continental Europe (using the example of Germany and France) based on the analysis of scientific literature and civil legislation of France and Germany.
\end{abstract}

Keywords-private land ownership; proprietary rights; land legislation; continental European law; civil European law.

\section{INTRODUCTION}

Possession of the land ownership actually establishes physical proximity to a particular plot of land. This right means a legal requirement for a certain personal space on this land, as well as the right to dispose of this land at its discretion [5]. This means evaluating this land as its own, that is, a person has a certain relationship with this land, which is associated with the owner's personality, his/her autonomy. Ownership means that the owner has the authority to control his/her ownership. Property is a fortress of individual freedom and independence in the European liberal sense [6], [7].

But as it turns out in practice, the landholder has practically no complete freedom in the land use. Restrictions on the types of activities for which land can be used are widely applied in the field of planning legislation, for example, the right to divide plots of land for sale can be restricted. Legislation on the protection of public health and environmental protection also restricts certain types of activities or prevents the implementation of certain types of activities that could be undertaken on a plot, and prescribes how they should be carried out. Usually, certain types of land use can be carried out only based on a permit, which, in turn, determines the conditions for the use of land [8]. Moreover, the fear of filing a claim for damages, if the plot was used in a way that caused damage to the property of others, can serve as a practical ban on some type of activity [1], [4].

\section{MATERIALS}

A classic example of how the content of title to land is determined is the French Civil Code (FCC), Art. 552 of which 
demand his/her property. The term for filing such a claim is one year. After this period, the claim shall not be satisfied if the owner of the land on which the sediment occurred did not take possession of it [2].

As a general rule, islands, small islands, shallows, which are formed at the bottom of water flows, regardless of whether they are navigable or floating, belong to the State. The islands and shallows, which are formed on non-navigable streams and non-floating rivers, belong to the owners of coastal land plots of the bank to which the formed islands and shallows adjoin. If the formed island does not adjoin the coast, it belongs to the coastal owners from both banks, starting from the line drawn in the middle of the river (Art. 561 of the FCC) [2].

If a water flow (river) forms a new bed, washing away and surrounding a plot of a coastal owner and creating an island, then this owner retains his/her ownership right to this plot regardless of whether it was formed on a navigable or floating water flow (river) (Art. 562 of the FCC). When a navigable river or water flow forms a new bed, leaving the former bed, coastal owners can acquire ownership of this former bed until its middle. The price of the land of the former bed is determined by experts appointed by the court at the location of the land at the request of the prefect. If the coastal owners have not been able within three months from the receipt of the prefect's notice to express their intention to buy land at prices determined by experts, the former bottom plot is sold, according to the rules governing the sale of the State's property. The amount received from the sale is compensation to the owners of real estate, along which a new river bed has been laid; the compensation is distributed in proportion to the value of the land "taken" from each of them (Art. 563 of the FCC) [2].

The Code governs the issue of runoff of water entering the land as precipitation. So, according to Art. 640 of the FCC, lower-lying plots of real estate are subordinate plots located above, which is aimed at obtaining water that naturally flows from them without the application of human labor and its assistance. The owner of the downstream plot cannot erect dams to prevent such runoff. The owner of the upper plot cannot do anything that worsens the easement conditions of water flow in relation to the lower plot of land [2].

The owner has the right to use and dispose of rainwater that falls on his/her property. When the use of such waters or the paved direction of their flow affects the conditions of the natural flow easement established, in accordance with Art. 640 of the FCC, the landholder is entitled to compensation. The same provision should apply to spring waters formed on the plot. If drilling or underground work performed by the owner leads to runoff from his/her land plot, the owners of the downstream plots are obliged to accept it, but are entitled to compensation for damage to the houses, yards, gardens, parks, and plots adjacent to residential buildings. In these cases, the easement of water flow does not apply (Art. 641 of the FCC) [2].

The issues related to the use of well water are specifically regulated. A person who has a well on the plot can always use the water from it at will for his/her needs within the volume of water. The owner of the well does not have the right to use part of the coastal land to the underlying plot or the opposite bank, the owner of the demolished part of the land can 
The issue of the correlation of the title to land and title to water from it to the detriment of the owners of the lower plots, which for more than 30 years created and performed on the plot where the water flows, visible and permanent work with the intention of using this water and providing a drain of water from their plots. As a general rule, the owner of the well cannot use it in such a way as to deprive the residents of the commune or village of the water they need (Art. 642 of the FCC) [2].

When well water flows from the land plot and forms a bed, which is public water by nature, the owner does not have the right to change their natural flow to the detriment of downstream users. According to Art. 644 of the FCC, a person whose plot borders a current water flow that is publicly owned can use it to irrigate their area.

In the case of a dispute between landholders who use such waters, the courts in their decisions should reconcile the interests of using such waters for agricultural needs with the interests of the rights of owners; in all cases, special and local rules regarding water use practices should apply (Art. 645 of the FCC [2]).

Features of the title to land in Germany are regulated by the German Civil Code (GCC). According to Raymond Leger, the GCC developed with great efforts is opposed to the FCC both in form and in content. The compilation of the GCC testifies to the desire to achieve certainty, which turns into scientific accuracy: each term was chosen so that it was used with only one meaning (in the FCC, on the contrary, most terms have several meanings). In terms of content, the Code is far from being based on innovative, political, and social principles. It is in harmony with the ideals of liberal individualism of the $19^{\text {th }}$ century [3].

The contents of the property right are reflected in Art. 905 of the GCC. The title to land extends into the space above and below the surface of the land. However, the landholder cannot prohibit activities carried out at a height or depth that does not arouse his/her interest [3]. wildlife has been specifically resolved (Art. 960 of the GCC). Wildlife does not have an owner while they are free. This means that in Germany, there is no title to wildlife in a state of natural freedom. However, wildlife in the zoo and fish in ponds or other waters that are privately owned are not ownerless, that is, under such conditions, they are recognized as objects of ownership [3].

\section{CONCLUSION}

Studying the European experience of developing the institution of private land ownership, it seems to us possible to further determine the typological features of the formation and development of property rights, in particular the right of private land ownership in the Russian Federation.

\section{References}

[1] Anners E. History of European Law. M.: Nauka, 1994. 397 pp.

[2] French Civil Code (Napoleon Code) of March 21, 1804 (amended and additional as of September 1, 2011)

[3] German Civil Code (GCC, Bürgerliches Gesetzbuch) dated 08/18/1896 (as amended on 02/02/2002) dated August 18, 1896 (amended on January 2, 2002) (amended and supplemented as of March 31, 2013)

[4] David R., Jauffret-Spinosi C. The main legal systems of our time. M.: International Relations, 1999. 400 pp.

[5] Kulisher I.M. The History of Economic Life in Western Europe. $9^{\text {th }}$ ed. Vol. 1-2. Ch.: Sotsium, 2004. P. 1030.

[6] Agriculture and Economic Development in Europe Since 1870 / Edited by P. Lains, V. Pinilla. Routledge, 2009. P. 108.

[7] Agriculture, Trade and Food Security Issues and Options in the WTO Negotiations from the Perspective of Developing Countries. FAO 2000. Vol. II Chapter 6.

[8] Johnson D. G. The Role of Agriculture in Economic Development. Clawson, 1963. P. 5. 